\title{
The recreational value of river inflows into South African estuaries
}

\author{
Stephen Hosking* \\ Department of Economics, Nelson Mandela Metropolitan University (NMMU), PO Box 77000, Port Elizabeth, 6031, South Africa
}

\begin{abstract}
Estuarine habitats are subject to increasing demand pressures. Some of these are direct, for the appealing space they provide for residences and recreation; and some are indirect, in the form of competitive demand for the inputs required to maintain their ecological functionality, for instance, river inflows. As a result of increasing demand for river water the connection of many of South Africa's estuaries with the sea has been undermined and their recreational appeal reduced. This paper reports findings on these negative impacts for selected estuaries. The contingent valuation method was used to estimate the value of recreational benefits that would result at 40 South African estuaries if water-inflow reductions were averted. The studies were undertaken between 2000 and 2007. All the estuaries selected were known to be vulnerable to changes in river inflows. Expert opinions on the consequences of specified hypothetical changes to water inflows into estuaries were used to generate the scenarios valued. User populations were estimated and surveys administered to samples of these populations. From the elicited responses median estuary user willingness to pay bids were predicted using Tobit and OLS models. An internal credibility assessment was conducted over the plausibility of the predictive model, the consistency of the values to those estimated using an alternative valuation method (the contingent travel cost method), and the reliability of the estimates. For the 37 estimates deemed reliable (but not necessarily valid), the average of the predicted median values of river inflow into estuaries was calculated to be $3.4 \mathrm{c} / \mathrm{m}^{3}$ (South African cents, ZAR) and standard deviation $3.84 \mathrm{c} / \mathrm{m}^{3}$. The average of the predicted mean values was calculated to be $7.4 \mathrm{c} / \mathrm{m}^{3}$ and the standard deviation $6.7 \mathrm{c} / \mathrm{m}^{3}$. It was also found that where there had been extensive economic development around the river system, the values of inflows into estuaries tended to be less than the value of water abstracted upstream.
\end{abstract}

Keywords: recreational value, river inflows, estuaries, South Africa

\section{Introduction}

Estuaries attract demand for a number of reasons. They provide aesthetically appealing environments in which to live, a habitat and nursery for fish and birds and water space that can accommodate a wide range of non-extractive non-rival recreational pursuits, as well as extractive rival ones (Hay et al., 2010: 6-10). These features serve to complement adjacent recreational attractions, such as beaches and natural indigenously vegetated banks, thereby enhancing the overall appeal of a particular location/resort to people (Hay et al., 2010: 6-10).

People find estuaries attractive and the pressure exerted impacts the very attractiveness that draws people to the estuaries in the first place, through activities such as:

- Reducing inputs that sustain the estuary habitats, including freshwater inflow

- Depleting fish (and other natural) stocks in estuaries (Rogers, 2011)

- A range of direct physical impositions, like transport infrastructure, disposed of human effluent and litter, and discharged agricultural and industrial chemicals (Schalacher and Wooldridge, 1996; Adams, 2001).

The magnitude of these activities is illustrated by the number of estuarine fishers and their catch. Along South Africa's

This paper was originally presented at the Water Research Commission 40-Year Celebration Conference, Kempton Park,

31 August - 1 September 2011.

* To whom all correspondence should be addressed.

III +2741 5042638; fax: +27 41 5042574; e-mail: stephen.hosking@nmmu.ac.za
$3100 \mathrm{~km}$ coastline, 73812 fishers (line fishers, cast netters, gill netters, seine netters and traditional trapping) exploit its approximately 255 functional estuaries, to catch an estimated 2481 tons of fish per year in the estuaries, and about 27519 tons of estuarine-dependent fish (as a nursery) per year in the sea (Lamberth and Turpie, 2003). Almost 99\% of this fishing is for recreational purposes. This activity has a substantial associated economic impact. The economic contribution to Gross Domestic Product (GDP) of the estuarine fishery industry has been (very roughly) estimated by McGrath et al. (1997) to be R432 959465 (1997 price levels), and that of the estuarine-dependent (as a nursery) marine inshore fishery at R518 790000 (1997 price levels). These estimates were based on catch information from the National Marine Linefish System database and Hutchings and Lamberth (1999).

The pressures on South Africa's estuaries are set to escalate. South African real GDP has increased about tenfold since 1946, the year when the Annual National Accounts were first generated for South Africa (Fedderke and Simkins, 2006 and the author's own calculations), and there is good reason to believe that future governments will be just as committed to economic growth as past ones. Increased income translates into increasing demand for all things, including potable water, water for agriculture and estuary-linked recreational opportunities. Increased pressure on the resource upstream will decrease the quality and quantity of freshwater flowing into estuaries, in turn eroding the benefits that society derives from estuaries.

The control of the freshwater inputs into estuaries is regulated by the National Water Act of 1998. This Act requires that sufficient freshwater must be allocated to maintain the ecology of rivers and estuaries. In recognition of the pressure on the nation's water resources, the Act has instituted the Reserve in 
order to protect ecosystem functioning and the benefits that ecosystems deliver to people. However, the 1998 National Water Act, when viewed in isolation, does not address the real challenges confronting South African estuaries - escalating population and demand pressure. 'Turning back the clock' to restore estuarine ecological functionality to a pristine state may be possible in isolated cases, but is not a feasible management objective for the majority of South African estuaries. The major challenge confronting the managers of South Africa's estuaries and public policy is resolving the trade-offs between the competing demand for the ecosystem services provided by estuaries. This challenge is recognised in a Classification System that assigns a management class to the resource, with Class I being minimally used and Class III being heavily used.

Meeting the challenge requires guidance to be provided on striking the right balance between different demand interests, for instance:

- Between demand for upstream abstraction of river flows before they reach the estuaries, and demand for ecologically functional estuarine habitats for bait, fish, birds and mangroves

- Between the demand to dispose of human and industrial effluent into water that enters estuaries, and demand for recreational use of these estuaries

- Between short-run extractive recreational and subsistence demand for the fish, bait and mangroves in the estuary, and their long-run supply, also known as sustainability (Lamberth and Turpie, 2003)

- Between demand for public spending on service-provision enhancement of the recreational appeal of the estuary (providing public (open) access to estuary and its attractions, changing and ablution facilities and safety in and out of the water) and demand for public spending on other services (housing, health, roads and so on)

- Between the demand for access to the estuary space among the population of boat owners and the demand for use of the estuary space by other categories of users (like shore-based fishers, residents and owners of other craft)

- Between the demand by residents for exclusive access rights to the estuary and its banks and the demand by visitors for open access

Economics claims to be able to inform public management on the right balance with respect to a number of these competing or conflicting demands (Lamberth and Turpie, 2003; Field and Field, 2004), provided that it has sufficient information about the relevant resources. Often there is insufficient or inadequate information available, leading to highly qualified guidance being offered. For instance, with respect to demand conflict over extractive recreational fishing activity, Lamberth and Turpie (2003) deduce that 14 of the 80 utilised estuary-associated species are overexploited and six of these in a collapsed state, but point out that their deduction is based on inadequate information about most of the 80 fish species.

Building on the Lamberth and Turpie (2003) call for economic values to guide the management of estuaries, this paper explores the claim that economics can provide insight into the balance between human demand for abstraction of river inflows into estuaries and the human demand for healthy estuary habitats for fish, birds, bait and mangroves. The findings reported and discussed are recreational values of freshwater inflows into 40 South African estuaries estimated between 2000 and 2007. The values were generated using the contingent valuation method (CVM).
Details of the application of the method are not discussed in this paper, as they have already been adequately covered in other papers. For instance, on the way this method was applied at individual estuaries see Hosking and Du Preez (2004), Hosking (2007) and Sale et al. (2009), and on the way the validation tests were generated see Du Preez and Hosking (2010).

\section{Freshwater deprivation and estuary ecological functionality}

Being last in the queue for freshwater supply, estuaries have borne the brunt of the consequence of freshwater scarcity in South Africa (Whitfield and Wooldridge, 1994), and so 'find themselves in the eye of a very complex storm' of competition for freshwater (Hay et al., 2010). The storm has its roots in the increased demand for potable water, water for agriculture and forestry expansion and by-products, and has taken the form of reduced natural freshwater inflow into South Africa's river systems (Hosking, 2010). As a result, the ecological functionality of these river systems, estuaries in particular, has been undermined (Schalacher and Wooldridge, 1996; Adams, 2001). The negative ecological impact on estuaries has had the knockon effect of compromising their recreational appeal to specific classes of users, like fishers, thereby undermining their recreational value (Whitfield and Wooldridge, 1994). In the nomenclature of economics, a trade-off has emerged between the demand to abstract river flows and the demand for recreational services in estuaries that are linked to the recreational service provided by the estuary. Economics can provide guidance on what would be an efficient trade-off by estimating the value of the marginal unit of water abstracted from a river and the value of the marginal unit of water allowed to flow into estuaries and comparing these 2 values (Hosking, 2008).

\section{The determination of an efficient inflow of water into an estuary}

When adequately applied, CVM is an acceptable method for generating the value of the inflow into an estuary (Hosking and Du Preez, 2004; Hosking, 2007). An extensive set of guidelines have to be adhered to in order to meet this criterion (Arrow et al., 1993; Videira et al., 2007).

Where these willingness to pay values exceed the value of the water abstracted upstream of the estuary it is efficient to allow the water to flow into the estuary (Hosking, 2008). The values of water are not static, but continually change as relative scarcity and demand change. For this reason, these values need to be updated for them to remain relevant. The group of users who were selected to elicit their willingness to pay (WTP) for a hypothetical project to prevent the reduction in river inflow into the estuary, were mainly direct recreational users, but also included some passive users (residents and visitors). In order to make the scenario valued as relevant as possible for the participants, they were presented with a set of changes that were deemed realistic by a panel of estuarine experts. The scenario was not generated (predicted) with reference to models such as the Estuarine Systems Model or Estuarine Ecosystem Evaluation Model or any other linked system modelling the consequences for estuaries of upstream abstraction (Slinger, 2000), but many of the contributors to these modelling exercises also played a role in determining the scenarios. The scenarios were generated from 2 sets of forecasts. The first was a forecast of changes in riverwater inflows during the forthcoming 2 decades into selected South African estuaries generated by the Department of Water 


\begin{tabular}{|l|l|l|l|l|}
\hline \multicolumn{5}{|c|}{ Examples of hypothetical changes in services provided by the selected estuaries } \\
\cline { 2 - 5 } & Bushmans & Keiskamma & Kleinemond East & Tyolomnqa \\
\hline Recreational service & No & No & Yes & Yes \\
\hline Mouth closure & No change & $10 \%$ decrease & $10 \%$ decrease & $10 \%$ decrease \\
\hline Boaters and swimmers & $33 \%$ reduction & $10 \%$ decrease & $50 \%$ reduction & $25 \%$ reduction \\
\hline Fishers (angling fish) & No change & no change & no change & $10 \%$ reduction \\
\hline Bait collectors & No change & $10 \%$ reduction & $25 \%$ reduction & No change \\
\hline Birders & No change & no change & $10 \%$ change & No change \\
\hline Perspective of view & No change & $30 \%$ to $50 \%$ reduction & $10 \%$ reduction & $25 \%$ reduction \\
\hline Loss of unique habitats & 19 & 0.12 & 2.8 \\
\hline $\begin{array}{l}\text { Additional water required per annum } \\
\text { to avert DWAF reduction (million } \mathrm{m}^{3} \text { ) }\end{array}$ & 2.4 & & & \\
\hline
\end{tabular}

Affairs (and Forestry). The second was a forecast of how these specified changes in water inflows would impact on the recreational services yielded by the estuaries by a panel of estuarine scientists at a set of workshops held at the Nelson Mandela Metropolitan University, under the chairmanship of Prof. $\mathrm{T}$ Wooldridge. The respondents were asked to bid an amount of money (in ZAR) they would be willing to pay for a project to prevent these specified changes. The project interventions envisaged included catchment-area rehabilitation, restriction on damming and supplementary water-transfer schemes.

\section{The scenarios valued}

The panel chaired by Prof. Wooldridge provided 4 examples (shown in Table 1) of the hypothetical changes forecast in estuary recreational services as a result of changes in river inflows. A separate forecast was generated for each estuary (see subreport in CD of Hosking, 2010), based upon its unique characteristics. Similarities in impact were often observed, due to the similarity of water inflow reduction pressure.

\section{Estuary and respondent sample selection}

The sample of estuaries selected by the panel of estuarine scientists is shown in Table 2. At these estuaries a total of 7768 WTP bids were elicited during the period 2000 to 2007 , of which 6397 were deemed valid.

\section{Predictive modelling}

The WTP of the estuary users was predicted from a mixture of use and socio-economic related variables. For each estuary a complete model was fitted, following which a preferred reduced (predictive) model was generated through a backward stepwise regression procedure. In order to restrict predicted bids to nonnegative values, the predictive modelling mainly utilised Tobit models, but OLS models were also estimated for comparative purposes. Both mean and median WTP values were predicted. The distribution of the predicted WTP data was skewed for many of the estuaries in this study - causing big differences between some of the predicted mean and median WTP values, with the mean values exceeding the median ones. The use of medians diminished the influence of the minority higher bidding (wealthier) group on the predicted value.

\section{The WTP Results}

The total WTP results were calculated from the predicted mean and median WTP values. Three examples are shown in Table 3, namely those of the Bushmans, Keiskamma and Nahoon Estuaries.

In similar fashion the value of water inflows for the other estuaries was calculated (see Table 4).

The WTP bids were elicited in different years from 2000 to 2007, over which time the Consumer Price Index (CPI) increased by $51 \%$. Accordingly, estimates had to be corrected for inflation.

A positive WTP was predicted for purchases of river inflows into most of the estuaries in this sample. The averages for all 40 estuaries of the predicted means and median WTP bids and the standard deviations about the averages are shown in Table 5.

The average predicted mean and median values per cubic metre inflow purchased for the 40 estuaries are $36 \mathrm{c} / \mathrm{m}^{3}$ and $11 \mathrm{c} / \mathrm{m}^{3}$, respectively. The standard deviations about average of the mean and median predicted values, respectively, are $107 \mathrm{c}$ and $44 \mathrm{c}$.

There is considerable variation between the estuaries in the predicted WTP. The water inflow required for the St Lucia Estuary was so great relative to the total WTP that the WTP/ $\mathrm{m}^{3}$ was reduced to negligible levels. Both the mean and median predicted water WTP values for freshwater inflow into the St Lucia Estuary were found to be $\mathrm{R} 0.00 / \mathrm{m}^{3}$ (Table 4). By way of contrast, a relatively small change in river-water inflow was required for the Kleinemonde West Estuary, leading to mean and median predicted water values being found in excess of $\mathrm{R} 2.50 / \mathrm{m}^{3}$.

\section{Assessing the credibility of results}

The masters students who administered the surveys admitted that in their data it was often almost impossible to exclude embedding bias, information asymmetry and moral and strategic rather than budget motivated bidding, inter alia, in the administration of the questionnaires, and the rigor of the pilot testing was often less than ideal (Videira et al., 2007). Without doubt many of the standard complications associated with the application of the contingent valuation method were also present in varying degrees in the various estimates (see further discussion of these problems in Videira et al., 2007) .

Under the circumstances, an internal assessment of the credibility of these estimates was thought to be of particular importance. The internal credibility assessment incorporated the following criteria: the plausibility of the predictive model; the consistency of the values to those estimated using an alternative valuation method (the contingent travel cost method); and the reliability of the estimates (based on outlier identification). The assessment identified 14 estimates out of 40 as 


\begin{tabular}{|c|c|c|c|c|c|}
\hline & ary and respondent & $\begin{array}{l}\text { Table } 2 \\
\text { ion (list }\end{array}$ & rder est & urveyed & \\
\hline Estuary & Analyst $^{\#}$ & Year & Sample & Valid & Users/a \\
\hline Keurbooms & Du Preez & 2000 & 150 & 120 & 3312 \\
\hline Groot Brak HB* & Dimopolous & 2002 & 151 & 151 & 2730 \\
\hline Swartkops HB & Lin & 2002 & 200 & 200 & 5200 \\
\hline Kowie HB & Lin & 2002 & 150 & 100 & 3234 \\
\hline Kariega HB & Lin & 2002 & 100 & 100 & 2000 \\
\hline Klein Brak HB & Dimopolous & 2002 & 101 & 101 & 1178 \\
\hline Knysna HB & Dimopolous & 2002 & 201 & 201 & 3891 \\
\hline Kromme HB & Lin & 2002 & 150 & 150 & 3200 \\
\hline Mngazana & Mlangeni/Potgieter & 2003 & 107 & 107 & 2500 \\
\hline Mngazi & Mlangeni/Potgieter & 2003 & 143 & 103 & 7000 \\
\hline Bira & Vd West & 2004 & 83 & 68 & 1250 \\
\hline Bushmans & Vd West & 2004 & 300 & 229 & 2800 \\
\hline Kasouga & Vd West & 2004 & 151 & 135 & 1875 \\
\hline Keiskamma & Vd West & 2004 & 251 & 220 & 2800 \\
\hline Kleinemonde East & Vd West & 2004 & 151 & 128 & 1875 \\
\hline Nahoon & Vd West & 2004 & 294 & 270 & 2800 \\
\hline Tyolomnqa & Vd West & 2004 & 150 & 150 & 1875 \\
\hline Heuningnes & Dikgang & 2005 & 216 & 187 & 1325 \\
\hline Kleinmond & Dikgang & 2005 & 250 & 212 & 4482 \\
\hline Klein & Dikgang & 2005 & 249 & 187 & 4482 \\
\hline Palmiet & Dikgang & 2005 & 293 & 258 & 3878 \\
\hline Cefane & Dikgang & 2005 & 62 & 42 & 1250 \\
\hline Kwelera & Dikgang & 2005 & 101 & 63 & 2500 \\
\hline Haga-Haga & Dikgang & 2005 & 112 & 100 & 2573 \\
\hline Olifants & Akoto & 2006 & 95 & 80 & 500 \\
\hline Great Berg & Akoto & 2006 & 268 & 248 & 2000 \\
\hline Breede & Akoto & 2006 & 180 & 161 & 1328 \\
\hline Duiwenhoks & Akoto & 2006 & 30 & 28 & 100 \\
\hline Swartvlei & Akoto & 2006 & 352 & 337 & 4000 \\
\hline Kleinemonde West & Akoto & 2006 & 150 & 132 & 1250 \\
\hline Mlalazi & Akoto & 2006 & 344 & 340 & 1500 \\
\hline Mhlathuze & Akoto & 2006 & 292 & 286 & 725 \\
\hline Gqunube & Nyaboga & 2007 & 301 & 212 & 5661 \\
\hline St Lucia & Nyaboga & 2007 & 300 & 261 & 3218 \\
\hline Uilskraals & Nyaboga & 2007 & 150 & 103 & 2168 \\
\hline Gamtoos & Chege & 2007 & 260 & 141 & 5000 \\
\hline Sundays & Chege & 2007 & 210 & 136 & 8300 \\
\hline Mgeni & Chege & 2007 & 210 & 113 & 4414 \\
\hline Mvoti & Chege & 2007 & 300 & 95 & 1500 \\
\hline Mdloti & Chege & 2007 & 210 & 142 & 2730 \\
\hline \multicolumn{3}{|l|}{ Total count } & 7768 & 6397 & 114404 \\
\hline
\end{tabular}

Table 3

The predicted WTP and TWTP (ZAR) per estuary - estimated using Tobit models

\begin{tabular}{|l|c|c|c|}
\hline \multirow{2}{*}{} & \multicolumn{3}{|c|}{ Estuary } \\
\cline { 2 - 4 } & Bushmans (recreation) & Keiskamma (subsist) & Nahoon(in city) \\
\hline User population (households) & 2800 & 2800 & 2800 \\
\hline Water required (million $\mathrm{m}^{3}$ ) & 2.4 & 19 & 3.780 \\
\hline WTP - mean (Rand) & 253 & 77 & 58 \\
\hline WTP - median (Rand) & 118 & 4 & 30 \\
\hline TWTP - mean (Rand) & 708400 & 215600 & 162400 \\
\hline TWTP - median (Rand) & 330400 & 11200 & 84000 \\
\hline Value of water - mean base $\left(\mathrm{c} / \mathrm{m}^{3}\right)$ & $29.52 \mathrm{c}$ & $1.13 \mathrm{c}$ & $4.30 \mathrm{c}$ \\
\hline Value of water - median base $\left(\mathrm{c} / \mathrm{m}^{3}\right)$ & $13.77 \mathrm{c}$ & $.06 \mathrm{c}$ & $2.22 \mathrm{c}$ \\
\hline
\end{tabular}




\begin{tabular}{|c|c|c|c|}
\hline \multicolumn{4}{|c|}{$\begin{array}{c}\text { Table } 4 \\
\begin{array}{c}\text { Estimated price level (ZAR) adjusted values } \\
\text { of water at each estuary* }\end{array}\end{array}$} \\
\hline Estuary & $\begin{array}{c}\text { Change } \\
\text { in inflow } \\
\text { of water } \\
\text { (millions } \\
\mathrm{m}^{3} / \mathrm{a} \text { ) }\end{array}$ & $\begin{array}{c}\text { Mean } \\
\text { predicted } \\
\text { value of } \\
\text { water }\left(R / \mathrm{m}^{3}\right)\end{array}$ & $\begin{array}{c}\text { Median } \\
\text { predicted } \\
\text { value of } \\
\text { water }\left(R / \mathrm{m}^{3}\right)\end{array}$ \\
\hline Olifants & 0.50 & 0.0044 & 0.0021 \\
\hline Great Berg & 74.9 & 0.0033 & 0.0015 \\
\hline Palmiet & 3.88 & 0.0416 & 0.0394 \\
\hline Kleinmond (Bot) & 4.22 & 0.0503 & 0.0044 \\
\hline Klein & 4.00 & 0.0915 & 0.0546 \\
\hline Uilskraals & 2.17 & 0.1034 & 0.0270 \\
\hline Heuningnes & 2.70 & 0.0120 & 0.0022 \\
\hline Breede & 21.10 & 0.0133 & 0.0109 \\
\hline Duiwenhoks & 0.50 & 0.0051 & 0.0011 \\
\hline Klein Brak HB & 11.20 & 0.0136 & 0.0126 \\
\hline Groot Brak HB & 5.00 & 0.1485 & 0.1048 \\
\hline Swartvlei & 5.50 & 0.0100 & 0.0061 \\
\hline Knysna HB & 46.00 & 0.0168 & 0.0126 \\
\hline Keurbooms & 78.5 & 0.0129 & 0.0125 \\
\hline Kromme HB & 75.50 & 0.0158 & 0.0122 \\
\hline Gamtoos & 0.36 & 4.7278 & 0.4472 \\
\hline Swartkops HB & 14.04 & 0.1141 & 0.0904 \\
\hline Sundays & 2.16 & 0.2562 & 0.0261 \\
\hline Bushmans & 2.40 & 0.2952 & 0.1377 \\
\hline Kariega HB & 7.40 & 0.1027 & 0.0570 \\
\hline Kasouga & 0.38 & 0.5329 & 0.3503 \\
\hline Kowie HB & 13.00 & 0.0809 & 0.0721 \\
\hline Kleinemonde West & 0.10 & 4.3404 & 2.7676 \\
\hline Kleinemonde East & 0.12 & 2.9063 & 0.0469 \\
\hline Bira & 1.44 & 0.2049 & 0.1016 \\
\hline Keiskamma & 19.08 & 0.0113 & 0.0006 \\
\hline Tyolomnqa & 2.80 & 0.0743 & 0.0027 \\
\hline Nahoon & 3.78 & 0.0430 & 0.0222 \\
\hline Gqunube & 5.23 & 0.0324 & 0.0075 \\
\hline Kwelera & 16.88 & 0.0609 & 0.0048 \\
\hline Cefane & 13.50 & 0.0218 & 0.0129 \\
\hline Haga-Haga & 15.44 & 0.0188 & 0.0128 \\
\hline Mngazana & 10.62 & 0.0697 & 0.0231 \\
\hline Mngazi & 14.14 & 0.0089 & 0.0063 \\
\hline Mgeni & 26.90 & 0.0373 & 0.0008 \\
\hline Mdloti & 2.06 & 0.0551 & 0.0193 \\
\hline Mvoti & 8.97 & 0.0127 & 0.0068 \\
\hline Mlalazi & 8.70 & 0.0044 & 0.0036 \\
\hline Mhlathuze & 9.90 & 0.0033 & 0.0023 \\
\hline St Lucia & 891.0 & 0.0002 & 0.0000 \\
\hline
\end{tabular}

*Values adjusted to 2008 price levels. Estuaries are listed from west to east.

having prima facie cause for querying their validity or reliability. These estimates are listed in Table 6

There was reason found to query the validity of 11 of the estimates and the reliability of 3 estimates. When the 3 estimates identified as unreliable, viz. Gamtoos, Kasouga and Kleinemonde West, are excluded from the calculations, the average predicted values fall dramatically (see Table 7). These 3 estimates are outliers in the sense that they lie further

\begin{tabular}{|l|l|c|c|}
\hline \multicolumn{4}{|c|}{$\begin{array}{c}\text { Table 5 } \\
\text { Average predicted mean and median } \\
\text { willingness to pay (ZAR) per } \mathbf{m}^{3}\end{array}$} \\
\hline \multicolumn{2}{|c|}{} & $\begin{array}{c}\text { Mean predicted } \\
\text { value of water } \\
\left(\mathbf{c} / \mathbf{m}^{3}\right)\end{array}$ & $\begin{array}{c}\text { Median predicted } \\
\text { value of water } \\
\left.\text { (c/m } / \mathbf{m}^{3}\right)\end{array}$ \\
\hline \multirow{2}{*}{$\begin{array}{l}\text { All 40 } \\
\text { estuaries }\end{array}$} & Average & 36.4 & 11.3 \\
\cline { 2 - 4 } & Std dev & 107.3 & 44 \\
\hline
\end{tabular}

\begin{tabular}{|l|l|}
\hline $\begin{array}{c}\text { Median estimates of consumer surplus per } \text { m }^{3} \\
\text { for which evidence indicated uncertainty with } \\
\text { respect to validity or reliability }\end{array}$ \\
\hline Estuary & Reason to query validity \\
\hline Keurbooms & No validity assessment \\
\hline Swartkops & Poor predictive model \\
\hline Kowie & Poor predictive model \\
\hline Klein Brak & Poor predictive model \\
\hline Klein & Poor predictive model \\
\hline Kwalera & Poor predictive model \\
\hline Uilskraalmond & $\begin{array}{l}\text { Poor predictive model } \\
+ \text { divergent TC estimate* }\end{array}$ \\
\hline Kleinmond/Bot & Divergent TC estimate \\
\hline Olifants & Divergent TC estimate \\
\hline Mlalazi & Divergent TC estimate \\
\hline Gqunubie & Divergent TC estimate \\
\hline Gamtoos & $\begin{array}{l}\text { Divergent TC estimate } \\
+ \text { reliability doubtful }\end{array}$ \\
\hline Kleinemonde West & Reliability doubtful \\
\hline Kasouga & Reliability doubtful \\
\hline
\end{tabular}

*TC $=$ travel cost

\begin{tabular}{|l|l|c|c|}
\hline \multicolumn{4}{|c|}{ Table 7 } \\
\multicolumn{2}{|c|}{$\begin{array}{c}\text { Water inflow value (ZAR) summary statistics, excluding } \\
\text { unreliable estimates (2008 price levels) }\end{array}$} \\
\hline & & $\begin{array}{c}\text { Mean predicted } \\
\text { value of water } \\
\left.\text { (c/m } \mathbf{m}^{3}\right)\end{array}$ & $\begin{array}{c}\text { Median predicted } \\
\text { value of water } \\
\left.\text { (c/m } \mathbf{m}^{3}\right)\end{array}$ \\
\hline $\begin{array}{l}\text { 37 estuaries } \\
\text { (excl. outliers) }\end{array}$ & Mean & 7 & 3.4 \\
\cline { 2 - 4 } & Std dev & 6.7 & 3.8 \\
\hline
\end{tabular}

than 3 standard deviations from the mean (in the sample of 37 estuaries).

\section{Assessing the efficiency of inflows into estuaries considered for 2 estuaries}

For the purpose of assessing the efficiency of river-flow allocation into estuaries sufficient information was only generated for 2 cases, the Mngazi and Keurbooms Estuaries.

In the case of the Mngazi Estuary, Mlangeni (2006) and also Hosking (2010: 95) calculated the sample mean and median WTP values for water abstracted upstream, treated to potable quality and delivered to locations near their residences. Mlangeni (2006) estimated the WTP values to be:

$$
\begin{aligned}
& \text { Mean WTP } / \mathrm{m}^{3}=11.2 \mathrm{c} / \mathrm{m}^{3} \\
& \text { Median WTP } / \mathrm{m}^{3}=2.8 \mathrm{c} / \mathrm{m}^{3}
\end{aligned}
$$

The cost of treatment and water transfer $\left(\mathrm{R} 1.24 / \mathrm{m}^{3}\right)$ will have to be deducted from these values in order to generate a 


\begin{tabular}{|c|c|c|}
\hline \multicolumn{3}{|c|}{$\begin{array}{c}\text { Table } 8 \\
\begin{array}{c}\text { Efficiency comparisons of river inflows into the Mngazi } \\
\text { and Keurbooms Estuaries }\end{array}\end{array}$} \\
\hline Estuary & $\begin{array}{c}\text { Median WTP for } \\
\text { river inflow into } \\
\text { estuary } \\
\left(\mathrm{ZAR} \mathrm{c} / \mathrm{m}^{3}\right) \\
\end{array}$ & $\begin{array}{c}\text { Median WTP for abstracting } \\
\text { river inflow from the river } \\
\text { upstream of the estuary } \\
\left(\mathrm{ZAR} \mathrm{c} / \mathrm{m}^{3}\right)\end{array}$ \\
\hline Keurbooms & 1.3 & 13 (demand for agriculture) \\
\hline Mngazi & .7 & $\begin{array}{c}-122 \text { (stated WTP - prod } \\
\text { costs) }\end{array}$ \\
\hline
\end{tabular}

measure that may be compared to the river water flowing into the Mngazi Estuary (in situ). When this deduction is made, the mean and median $\mathrm{WTP} / \mathrm{m}^{3}$ values decline to negative values:

Mean WTP $/ \mathrm{m}^{3}=11-124=-114 \mathrm{c} / \mathrm{m}^{3}$

Median WTP $/ \mathrm{m}^{3}=2.8-124=-122 \mathrm{c} / \mathrm{m}^{3}$ (Hosking 2010:96)

By way of comparison with the value of water abstracted upstream of the estuary, Mlangeni (2006) calculated the sample median and mean WTP values (recreational demand) for freshwater flowing into the estuary to be $1 \mathrm{c} / \mathrm{m}^{3}$ (Table 4). About $30 \%$ of the respondents were willing to bid R 0.00 for the water flowing into the estuary, despite it being linked to bringing tourist spending into the area. The area in which the Mngazi Estuary is located is one of the poorest in South Africa.

The Keurbooms Estuary is located in one of the recreational playgrounds of the rich. Using a similar method of valuation, Du Preez (2002) calculated the median predicted WTP value for freshwater inflow into the Keurbooms to be $1.3 \mathrm{c} / \mathrm{m}^{3}$ and the WTP value to abstract the water upstream for agricultural use, to be $13 \mathrm{c} / \mathrm{m}^{3}$.

The findings of these 2 pilot efficiency comparisons of river inflows into the Mngazi and Keurbooms Estuaries are summarised in Table 8.

The comparisons in Table 8 show the marginal value of water flowing into the Mngazi and Keurbooms Estuaries to be similar (about $1 \mathrm{c} / \mathrm{m}^{3}$ of water), but the marginal (opportunity) cost to be very different. In the more developed region of the Keurbooms River, an alternative demand for the water for use in agriculture was found of $13 \mathrm{c} / \mathrm{m}^{3}$.In the relatively undeveloped and poor region of the Mngazi River, an alternative demand for potable water was also found, but it was less than the cost of abstracting and treating it (about $122 \mathrm{c} / \mathrm{m}^{3}$ less).

The comparisons in Table 8 are consistent with a theory that the value of water abstraction upstream of the estuary will typically exceed that of the water flowing into the estuary when this estuary is located in a highly developed region - and provides some evidence that there may be a tradeoff between economic development and maintaining ecological functionality of an estuary in South Africa. Recreational demand may not be enough, on its own, to hold back the undermining influence of economic development on estuarine ecological functionality in South Africa.

Two important qualifications to these findings are that:

- Efficiency is but one consideration on what is socially worthy

- It is improper to generalise across different estuaries and a wide range of time from findings specific to a given estuary and at a given point in time

An obvious distributional challenge related to the Mngazi Estuary is that of comparing the economic interest of local poor people, who are unable to pay the cost of potable water, with visitors to the area, who are able and willing to pay the cost of maintaining the recreational services provided by the estuary. The comparison of the WTP (bid) values of inflows into the Keurbooms Estuary is less socially problematic, because differences in income levels were not as apparent between the competing water-user groups.

\section{Conclusion}

At 2008 price levels, the average mean and median predicted recreational values of freshwater inflows into 37 selected South African estuaries were found to be $7 \mathrm{c} / \mathrm{m}^{3}$ and $3.4 \mathrm{c} / \mathrm{m}^{3}$ (ZAR, 2008 price levels), respectively, of river-water inflow. The contingent valuation method was applied and the period during which the bids were elicited was between 2000 and 2007. The respective standard deviations were $6.7 \mathrm{c} / \mathrm{m}^{3}$ and $3.8 \mathrm{c} / \mathrm{m}^{3}$ of water. An internal validity assessment found inconsistency for $35 \%$ of the estimates reported.

All other things being equal, the bigger the change in service for a given change in river inflow, the stronger was found the efficiency argument for additional freshwater-supply interventions (Table 4). This finding implies prioritising these estuaries for freshwater supplementation.

One of the key outcomes that could be sought through such a valuation analysis is the comparison between the opportunity cost of freshwater inflow into an estuary and the recreational value of the inflow into the estuary. Only 2 comparisons of this kind were attempted - for the Mngazi and Keurbooms Estuaries. For the Mngazi River it was found that an efficiency case could be made for reallocating water from abstractionrelated use to estuarine recreation-related use (leaving it in the river), but such a case could not be made with respect to the Keurbooms River. This case is a qualified one, as there were many other important factors to consider. The results of this analysis also point to a potential trade-off between estuarine ecological functionality and economic development.

\section{Acknowledgements}

In order to assist the Department of Water Affairs (DWA) and Catchment Management Agencies (CMAs) with the task of allocating and managing South Africa's water resources, South Africa's Water Research Commission has funded several studies into methods for determining and managing the setting of this Reserve during the decade after the National Water Act was passed - this one included. The author gratefully acknowledges the inputs into this paper of all of those who were members of WRC Project K5/1413 and are members of WRC Project K5/1924, as reference group and project team members, particularly Dr G Backeberg, the WRC project manager, and Ms JG Hosking, my research and administrative assistant. The author is also grateful to the anonymous referees and the guest editor for their valuable comments, and Ingrid Buchan for final editing. The specific WRC project reports that inform this paper are WRC Report No. 1413/1/10 (Hosking, 2010) and WRC Report No. TT 470/10 (Hay et al., 2010).

\section{References}

ADAMS JB (2001) The importance and freshwater requirements of South Africa's estuaries. SA Waterbulletin 26 (6) 16-19.

ARROW K, SOLOW R, PORTNEY PR, LERNER EE, RADNER R and SCHUMAN H (1993) Report on the NOAA Panel on Contingent Valuation. USA, Federal Register. 
DU PREEZ M and HOSKING S (2010) Estimating the recreational value of freshwater inflows into the Klein and Kwelera Estuaries: An application of the zonal travel cost method. Water $S A 36$ (5) 1-9.

DU PREEZ M (2002) Evaluating the Environmental Use of Water - Selected Case Studies in the Eastern and Southern Cape. Unpublished Doctoral Thesis. Nelson Mandela Metropolitan University, Port Elizabeth, South Africa.

FEDDERKE J and SIMKINS C (2006) Economic growth in South Africa since the late Nineteenth Century. Unpublished staff paper, School of Economics, University of Cape Town, South Africa.

FIELD BC and FIELD J (2004) Environmental Economics - An Introduction. McGraw-Hill, New York.

HAY D, HOSKING S and MCKENZIE M (2010) Estuaries, Economics and Freshwater: An Introduction. WRC Report No. TT 470/10. Water Research Commission, Pretoria, South Africa.

HOSKING S and DU PREEZ M (2004) Valuation of the freshwater inflows into the Keurbooms estuary by means of a contingent valuation study. S. Afr. J. Econ. Manage. Sci. 7 (2) 280-298.

HOSKING S (2007) Is there a need to audit CVM applications to the environment? S. Afr. J. Econ. Manage. Sci. 10 (4) 482-489.

HOSKING S (2008) An economic approach to allocating river water to estuaries in South Africa. Coast. Manage. J. 36 (1) 35-46.

HOSKING S (2010) The Valuation of Estuary Services in South Africa Specifically Regarding Changes to Estuary Services as a Result of Reductions to Freshwater Inflows - Main Report. WRC Report No. 1413/1/10. Water Research Commission, Pretoria, South Africa.

HUTCHINGS K and LAMBERTH SJ (1999) Management and Socio-Economic Considerations for the Drift and Beach-Seine Net Fisheries on the West and Southwestern Coasts of South Africa Final Report for Marine and Coastal Management, Department of Environmental Affairs and Tourism, Pretoria, South Africa.
LAMBERTH S and TURPIE J (2003) The Role of Estuaries in South African Fisheries: Economic Importance and Management Implications. WRC Report No. 756/2/03. Water Research Commission, Pretoria, South Africa.

McGRATH MD, HORNER CCM, BROUWER SL, LAMBERTH SJ, SAUER WHH and ERASMUS C (1997) An economic valuation of the South African linefishery. S. Afr. J. Mar. Sci. 18 203-211.

MLANGENI M (2006) A Contingent Valuation of River Inflows into the Swartkops, Kariega, Mngazi and Mngazana Estuaries in the Eastern Cape. Unpublished Masters Dissertation, Nelson Mandela Metropolitan University, Port Elizabeth, South Africa.

ROGERS G (2011) Protect dusky kob along with rhino - scientist. The Herald, 20 October, p. 7.

SALE M, DU PREEZ M and HOSKING S (2009) The recreation value of environmental services of the Kromme and Kowie estuaries. $S$. Afr. J. Econ. Manage. Sci. 35 (3) 261-270.

SCHALACHER TA and WOOLDRIDGE TH (1996) Ecological Responses to Reductions in Freshwater Supply and Quality in South Africa's Estuaries: Lessons for Management and Conservation. Opulus Press, Uppsala, Sweden.

SLINGER JH (2000) Decision Support for the Conservation and Management of Estuaries: Final Report of the Predictive Capability Sub-Project of the Co-ordinated Research Programme. WRC Report No. 577/2/00. Water Research Commission, Pretoria, South Africa.

VIDEIRA N, KALLIS G, ANTUNES P and SANTOS R (2007) Integrated Evaluation for Sustainable River Basin Governance. IWA Publishing, London, UK.

WHITFIELD AK and WOOLDRIDGE TH (1994) Changes to Freshwater Supplies to Southern African Estuaries: Some Theoretical and Practical Considerations. Olsen and Olsen, Fredensborg, Sweden. 
http://dx.doi.org/10.4314/wsa.v37i5.8 Available on website http://www.wrc.org.za

ISSN 0378-4738 $($ Print $)=$ Water SA Vol. 37 No. 5 WRC 40-Year Celebration Special Edition 2011 ISSN 1816-7950 (On-line $)=$ Water SA Vol. 37 No. 5 WRC 40-Year Celebration Special Edition 2011 